\title{
HIGHER EDUCATION FOR THE DEVELOPMENT OF LATVIA
}

\section{Summary \\ Introduction}

One of the preconditions for successful development of Latvia and competitive growth of its national economy is an appropriately functioning system of higher education.

\section{Aim of the Study}

To update the most significant tasks and activities of the contemporary higher education institutions in Latvia within the context of the country's competitiveness.

\section{Materials and Methods}

In the study, the author analyses theoretical sources, normative acts, research data on the conformity of the development of higher education with the needs of the national economy.

\section{Results}

The author characterises the support from the government and EU structural funds for the implementation of higher education growth possibilities for 2007-2013.

\section{Conclusions}

The enabling objectives include: elaboration and implementation of a modern legal framework; development and implementation of an array of flexible study programmes meeting the national and international standards; effective utilisation of the possibilities given by lifelong learning and further education; securing of an offer of study programmes matching the needs of the national economy.

Keywords: productivity of higher education; modernisation of study programmes; competitiveness.

\section{Introduction}

One of the preconditions for a successful development of Latvia and competitive growth of its national economy is an appropriate system of higher education. Currently, several conflicting tendencies can be observed in Latvia. On one hand, we see a rapid growth of the national economy; on the other hand, there is a high and persistent inflation, huge prevalence of import over export and an increase of the external debt.

Under the circumstances, one of the main goals in the economy in Latvia is to create an efficient and competitive structure of branches of national economy. To increase the competitiveness of the national economy in Latvia, it is necessary to apply a targeted innovation policy fostering accelerated development of science-capacious branches as well as a growth of production with a higher specific weight of added value in the traditional branches. The above line stands in position with general European priorities - the development of education, introduction of innovations and strengthening of cooperation among entrepreneurial, scientific and research institutions.

\section{Aim of the Study}

To update the most significant tasks and activities of the contemporary higher education institutions in Latvia within the context of the country's competitiveness. 


\section{Materials and Methods}

To encourage the development of the higher education system meeting the needs of Latvia's national economy, there are several tasks to be done with the help of public educational policy, suitable economic mechanisms as well as through the increase of the autonomy and responsibility of higher education institutions.

- Development and implementation of a modern legal framework. Together with social partners, the Ministry of Education and Science has provided the elaboration of a draft law on Higher education and has handed it to the Cabinet of Ministers.

- Development and implementation of an array of flexible study programmes meeting the national and international standards. Higher education in Latvia should be also seen as an export commodity therefore when devising study programmes one should come with unique and competitive proposals envisaging the development of inter-institutional and interdisciplinary programmes (for instance, in creative and processing industries, etc.) without copying the programmes available in other countries. Many higher education institutions have started the introductory work and have the first results, for instance, together with several higher education institutions in the Baltic region Riga Technical University has devised a master programme "Industrial Engineering and Management".

- Effective utilisation of the possibilities given by lifelong learning and further education. Higher education institutions have to become more open and need to offer their potential teaching staff, infrastructure, libraries - to any member of the society starting from secondary school leavers and ending with the unemployed, especially emphasising the necessity to master practical skills and knowledge and therefore organising work-based learning. Within the context of the competitiveness and development of Latvia, it is important that the higher education institutions are open, recognise and use the knowledge and skills acquired through informal learning. That would not only increase the number of applicants willing to study, but would also allow for more variations within study programmes and their modules.

- Securing of an offer of study programmes matching the needs of the national economy. First of all, this can be achieved through ensuring a more dynamic licensing procedure of the elaborated study programmes, decreasing the formal approach in elaborating the standards of professions and nevertheless taking into account the developmental interests for the country's national economy. Secondly, it is necessary to encourage education of specialists in export-capable branches. Thirdly, by promoting pre-service and in-service teacher education - well-educated teachers can influence and guide the choices of their students both - taking into account their abilities and interests, as well as the necessities of the country. Unfortunately, for many years after regaining the independence of Latvia, the public support for the teacher education programmes was incomprehensibly inadequate. As a result, many students choosing the above-mentioned programmes are covering tuition fees themselves. When the studies were finished, they ignored the high demand of teachers in the country and set out in search for more remunerative jobs.

This can be proved by a statement of Prof. Juris Krümiņš who spoke on a general meeting of Professors' Association of Higher Education Institutions of Latvia on February 7, 2008 showing the correlation between the salary and choice of the job as to the person's education. As we can see, it is exactly education and health sector where there is the biggest gap between the salary and the choice of one's education and acquired qualification (see Table 1). 
Table 1. The difference in the net salaries of the graduators according to the choice of the job and its relation to the acquired educational qualification (Krūmingš, 2008).

\begin{tabular}{|l|c|c|}
\hline Thematic field of education & $\begin{array}{c}\text { Profession matching the } \\
\text { acquired qualification }\end{array}$ & $\begin{array}{c}\text { Profession not matching the } \\
\text { acquired qualification }\end{array}$ \\
\hline Teachers' education & $\mathbf{2 1 8 ( 1 0 0 \% )}$ & $\mathbf{2 7 7}(\mathbf{1 2 7 \% )}$ \\
\hline The humanities and arts & $\mathbf{2 8 7}(\mathbf{1 0 0 \% )}$ & $\mathbf{3 2 7}(\mathbf{1 1 4 \% )}$ \\
\hline Natural sciences & $370(100 \%)$ & $335(91 \%)$ \\
\hline Agriculture & $\mathbf{2 4 0} \mathbf{( 1 0 0 \% )}$ & $\mathbf{2 7 6 ( 1 1 5 \% )}$ \\
\hline Health care and social well-being & $\mathbf{2 6 6 ( 1 0 0 \% )}$ & $\mathbf{3 9 4}(\mathbf{1 4 8 \% )}$ \\
\hline Services & $348(100 \%)$ & $294(84 \%)$ \\
\hline Commercial sciences and administration & $373(100 \%)$ & $327(88 \%)$ \\
\hline Law & $505(100 \%)$ & $271(54 \%)$ \\
\hline Engineering and technologies & $413(100 \%)$ & $374(91 \%)$ \\
\hline
\end{tabular}

\section{International Tendencies in Higher Education}

Being a member state of the European Union and taking active part in other international processes, Latvia develops in line with the rest of the world. In a similar way the higher education system in Latvia and space around it is being more and more incorporated into the international environment, especially within framework of the Bologna process. In connection with that an OECD study aiming at identifying the attitude of various stakeholders towards the funding systems and their effects on the development of the higher education system in general was carried out (Funding Systems and Their Effects on Higher Education Systems - International Report, 2007). There were nine project partners in the study: Austria, Czech Republic, Denmark, Germany, Ireland, Latvia, Norway, Portugal and Slovak Republic.

The results of the study show numerous significant tendencies in higher education. It is important to mention that the conclusions of the OECD study related to the development of higher education, are reflected in Latvia, i.e. - the main ideas have been included in all most significant policy planning documents and legislative acts as well as in the Latvian National Development Plan and governmental action plan:

○ Growth of autonomy and responsibility of higher education institutions, especially in economic aspects;

- Increase of efficiency and productiveness;

- Growth of international competitiveness;

$\circ$ Increase of the role of quality;

o Client orientation;

- Closer cooperation with the private sector and funding from it;

- Development of the Bologna process;

- Aims for the educational processes and fundamental and applicable scientific activities formulated in terms of quality;

○ Development of doctoral studies.

It has been concluded in the study that changes in the funding of higher education system accentuating monitoring instead of strict control will positively impact the development of higher education. Thus, the autonomy of higher education institutions, implementation quality and competitiveness will increase along with the efficiency of the higher education, its productivity and transparency. The changes will also encourage the internationalisation of the higher education and 
modernisation of the contents of the studies. Cooperation of higher education with other sectors will improve. The attention will be focused on students' needs and more flexibility of the budget will be possible. Autonomy and responsibility will also raise the managers', teaching staff's and students' motivation to work on further development and changes.

At the same time the study shows: changes in funding the higher education system might also have a negative impact on the development of the higher education. Thus, for instance, by concentrating on the efficient use of structural funds, there is a risk to diminish variety in study programmes and research. Higher education institutions also risk closing expensive programmes which, in turn, will negatively influence the development of fundamental sciences, etc.

On the whole, however, the aims in the development of higher education and their tendencies in other European countries match Latvia's aims, goals and development tendencies.

\section{Public Support for Ensuring the Development of Higher Education}

One of the preconditions for successful development of higher education is public support and national budget funding that has increased significantly over the last years (Law on National Budget for the Year 2008 (2008); Amendments of Law on National Budget for the Year 2007 (2007); Amendments of Law on National Budget for the Year 2006 (2006)). In 2008, the national budget under the section for the Ministry of Education and Science for funding the expenses in higher education is: LVL 122769 410; respectively in 2007 (including the Amendments of the National Budget) the sum constituted LVL 110838994 and in year 2006 - LVL 80253164.

Public support for higher education results in a larger number of budget study places as well as in state subsidies for one budget study place. Additionally, the public support for one study place has grown significantly over last three years, sometimes exceeding the tuition fee paid by students for several times (see Table 2).

Table 2. The budget financing includes only the funding from subsidies from overall incomings excluding the funding for the social provision of a study place that is LVL 146 as well as the funding for scientific research and special purpose grants.

(Survey on Higher Education in Latvia in the Year 2007, Ministry of Education and Science, 2008).

\begin{tabular}{|c|l|r|r|r|r|r|r|}
\hline \multirow{2}{*}{ No Thematic study group } & \multicolumn{3}{|c|}{ Tuition fee, LVL } & \multicolumn{3}{c|}{ Budget financing, LVL $^{1}$} \\
\cline { 3 - 7 } & & 2005 & 2006 & 2007 & 2005 & 2006 & 2007 \\
\hline 1. & Education & 545 & 683 & 841 & 850 & 877 & 1480 \\
\hline 2. & The humanities and arts & 739 & 878 & 1044 & 1115 & 1135 & 2159 \\
\hline 3. & Social sciences, commercial sciences and law & 655 & 816 & 1059 & 743 & 766 & 1273 \\
\hline 4. & Natural sciences, mathematics and ICT & 564 & 823 & 1087 & 1305 & 1359 & 2300 \\
\hline 5. & Engineering, manufacturing and building & 908 & 1081 & 1200 & 1299 & 1357 & 2482 \\
\hline 6. & Agriculture & 380 & 684 & $\mathbf{7 5 0}$ & 1685 & 1785 & $\mathbf{3 4 6 5}$ \\
\hline 7. & Health care and social well-being & 1007 & 1286 & $\mathbf{1 6 7 2}$ & 2442 & 2463 & $\mathbf{3 9 4 1}$ \\
\hline 8. & Services & 526 & 623 & 968 & 1419 & 1227 & 3440 \\
\hline & Average in total & $\mathbf{6 9 2}$ & $\mathbf{8 7 8}$ & $\mathbf{1 0 8 6}$ & $\mathbf{1 2 3 9}$ & $\mathbf{1 2 5 7}$ & $\mathbf{2 4 3 2}$ \\
\hline
\end{tabular}

\footnotetext{
${ }^{1}$ The budget financing includes only the funding from subsidies from overall incomings excluding the funding for the social provision of a study place that is LVL 146 as well as the funding for scientific research and special purpose grants.
} 


\section{Results}

\section{Growth Opportunities for Higher Education}

Even though the number of students has slightly decreased over the last years, nevertheless higher education in Latvia demonstrates growth potential and possibilities for qualitative development.

○ Autonomy and responsibility of higher education institutions. When higher education institutions obtain thelegal status of derived public persons, their autonomy in line with responsibility increase. Starting from 2009, the public higher education institutions will no longer be budget institutions. They will become budget financed institutions transiting from strict governmental control to financial monitoring. Along with the increase in autonomy and responsibility, there is going to be an increase in the responsibility of higher education institutions concerning the quality of the results after the studies to encourage not only higher attainments in higher education but also in employment by proportionally increasing the number of employers appropriate to acquired qualification among the graduators.

○ Real estate. Taking into consideration the fact that the number of students in Latvia is declining, it is important to ensure that the higher education institutions continue their development and should attract foreign students. Because of that, one of the ways to ensure the economic stability of higher education institutions with the help of clearly defined mechanism and rules and indirect state support is to gradually allow the real estate to become the property of universities, that is, the property of derived public persons.

○ International recognition and marketing of higher education institutions. In order to promote the overall image of Latvia its recognition in an international environment, it is necessary to share the responsibility among public institutions and private persons. There is no doubt that more discussions on the subject should be strongly encouraged. In the nearest future, the Ministry of Education and Science has intended to support a special section about Latvia, its higher education, science and development potential in journal Scientific American.

- Support from EU structural funds. Already in the previous planning period lasting from 2004 - to 2006, there was approx. LVL 25 millions invested in higher education. As a result, the support has been given to both students and teaching staff, the study environment, material and technical provision have been improved.

The new EU structural fund planning period from 2007 to 2013, on the other hand, will give a considerably greater support and investments in the development of higher education and science: more than 580 million euros. The sum shall be allotted for education of the teaching staff, especially, for work at school in teaching the priority subjects (16 million euros) as well as for material and technical provisions. Thus, for example, support for the next generation data transmission network for scientific research has been planned uniting the main education, science and innovation centres. Information systems in public scientific and educational institutions will also be improved.

\section{Conclusions}

\section{Challenges for the Development of Higher Education}

To be able to put a common effort in carrying out the above mentioned tasks and to ensure that higher education truly becomes the drive of the growth and development of Latvia, joint responsibility, understanding and trust between the higher education policy makers - the government, Ministry of Education and Science, social organisations, and implementers of the policy - higher education institutions, their management, teaching staff and students - are needed. Together we need to ensure that higher education becomes an export commodity so that the array of study programmes is 
innovative and flexible, so that it anyone irrespective of his/her age and prior education can find a suitable offer for personal development as well as for becoming a fully functioning and competitive member of the society throughout the lifetime.

\section{REFERENCES}

1. Funding Systems and Their Effects on Higher Education Systems - International Report" (2007) OECD Education Working Papers, No. 6, OECD Publishing. http://www.oecd.org/dataoecd/36/23/38279332. pdf (09.02.2008.)

2. Koḳe T., Muraškovska I. (2007) Latvija ceḷā uz zināšanu sabiedrību: izpratne un izaicinājumi. Izglītība zināšanu sabiedrības attīstībai Latvijā. Rīga: Zinātne, 121.-142. lpp.

3. Krūmiņš J., (2008.gada 7.febrāris) Profesūra Latvijā 2005.-2007. gadā: situācijas vērtējums un skats nākotnē. Runa biedrības „Latvijas Augstskolu profesoru asociācija” pilnsapulcē. Rīga.

4. Likums Par valsts budžetu 2008. gadam (2008), http://www.fm.gov.lv/page.php?id=3900 (09.02.2008)

5. Grozījumi likumāa „Par valsts budžetu 2007. gadam” (2007), http://www.fm.gov.lv/budzets/2007g/ likums.doc (09.02.2008)

6. Grozījumi likumā „Par valsts budžetu 2006. gadam” (2006) http://www.fm.gov.lv/budzets/2006g/ LP1915 g.doc (09.02.2008)

7. Pārskats par Latvijas augstāko izglītību 2007. gadā (2008) Rīga: Izglīîibas un zinātnes ministrija, 152. lpp.

Minister of Education and Science, Prof. Dr.habil.paed. Tatjana Koḳe

Ministry of Education and Science

Address: Vaḷnu iela 2, Rīga, LV-1050, Latvia

Phone: +371 67047810

E-mail: tatjana.koke@izm.gov.lv 